\title{
The European eel quality database: towards a pan-European monitoring of eel quality
}

\author{
Claude Belpaire • Caroline Geeraerts • Derek Evans • \\ Eleonora Ciccotti · Russell Poole
}

Received: 20 July 2010 / Accepted: 8 February 2011

(C) Springer Science+Business Media B.V. 2011

\begin{abstract}
The stocks of the European eel Anguilla anguilla are in decline and there is an increasing awareness that poor health status due to contaminants and/or diseases might be a key element in this decline and might be a hindrance to recovery. Many countries have started compiling data on the health status of eels in their water bodies. Objectives for these monitoring actions are diverse and there is a large amount of information collected by EU member countries. However, this information is widely scattered over Europe in agencies, institutes or universities. As there is a growing need to collect and report on data on the health status of the eel on international level, the Joint EIFAC/ICES Working Group on Eels initi-
\end{abstract}

C. Belpaire $(\varangle) \cdot$ C. Geeraerts

Research Institute for Nature and Forest,

Duboislaan 14, 1560 Groenendaal-Hoeilaart, Belgium

e-mail: claude.belpaire@inbo.be

D. Evans

Agri-Food \& Biosciences Institute for Northern

Ireland, Newforge Lane, Belfast, Northern Ireland

E. Ciccotti

Department of Biology, University of Rome

"Tor Vergata", Via della Ricerca Scientifica, 00133 Rome, Italy

R. Poole

Marine Institute, Aquaculture \& Catchment

Management Services, Newport, Co Mayo, Ireland ated in September 2007 the set up of an European Eel Quality Database to collect recent data of contaminants and diseases over the distribution area of the eel. This paper describes the aim, the set up and future development of the database in order to give it greater publicity and to call on scientists or managers to submit data on eel health status. The database represents now the first comprehensive pan-European compilation of eel health data, including data from over 10,000 eels from approximately 1,200 sites over 14 countries. Preliminary work has indicated a number of shortcomings and future developments will be needed. Guaranteeing further development of the database, harmonisation of methods, quality assurance, and setting up harmonised eel monitoring strategies over Europe will be a great challenge and will need pan-European cooperative work.

Keywords European eel • Contaminants •

Diseases $\cdot$ Database $\cdot$ Environmental monitoring

\section{Introduction}

Risk assessment for the protection of the human and environmental health relies on the identification of persistent, bioaccumulative and toxic substances. Measurements of the concentration of chemicals in the different abiotic compartments, including water, suspended particulate matter, 
and sediment, are usually associated with bioaccumulation analyses at the main trophic levels in the aquatic environment, because aquatic ecosystems are the final destination of any toxic input into the environment, from natural and/or anthropogenic sources. Bioaccumulation can be measured in invertebrate organisms as well as in vertebrates, among the latter fish are used because their value is commonly acknowledged and they respond to a variety of contaminants. Among fish, a number of species have been used as indicators of chemical status, selected on the basis of their ecological traits as well as of their bioaccumulation capacity. The European eel, Anguilla anguilla L., has proven to be a suitable species for the screening of toxic substances because this species bioaccumulates many substances in its muscle tissue (e.g. Bruslé 1991; de Boer and Hagel 1994; Maes et al. 2008), as a consequence of some specific physiological and ecological features (Belpaire and Goemans 2007a). Therefore, eel has been proposed as a chemical sentinel species (Belpaire et al. 2008), and more specifically as an indicator species for the chemical status within the Water Framework Directive (WFD; Belpaire and Goemans 2007b). High concentrations of contaminant burden in yellow eels from Belgium showed that most substances are present all over Flanders (northern part), but there is considerable variation between river basins, dependent on land use. It was shown that contaminant analysis in eel is able to pinpoint specific pollution sources, such as some volatile organic compounds in very specific locations, very high levels of brominated flame retardants (BFRs) in eels from areas with intensive textile industry, or high lindane levels in some rivers under agricultural pressure. Maes et al. (2008) demonstrated that banned chemicals like DDT are still in use in some places. Trend analysis within the 1994-2005 period indicated significant reductions in polychlorine biphenyls (PCBs) and many organochlorine pesticides (OCPs), and also for some heavy metals (lead, arsenic, nickel and chromium), concentrations decreased in the eel, but this was not the case for cadmium and mercury (Maes et al. 2008). Body burdens of lipophylic contaminants are considerably higher in eel than in other species (Belpaire and Goemans 2007b). Nationwide contaminant monitoring in eel allows a spatial view on environmental pressure gradients, potentially related to human health constraints. It also has direct applications supporting the management of professional or recreational fisheries in avoiding consumption of fish where legal consumption limits are exceeded.

Recently, there has been a growing awareness that contaminants and/or diseases might be key elements for the decline that the stock of the European eel is facing through its distribution range (Robinet and Feunteun 2002; Geeraerts and Belpaire 2010). Infestation of the swimbladder nematode Anguillicoloides crassus (Kuwahara, Niimi and Itagaki) may affect the capacity of European eels to complete their spawning migration (Palstra et al. 2007). Contamination (e.g. by PCBs) might impair fertility (Palstra et al. 2006) and affect lipid metabolism resulting in insufficient energy reserves to power successful migration and reproduction (Belpaire et al. 2009). The Council of the European Union established a framework and measures for the recovery and sustainable use of the stock of European eel (European Commission 2007) and requires the preparation and implementation of national Eel Management Plans. Within the guidelines for the preparation of these plans within this EC Regulation, the collection of data on the pollution and the disease status of eels of each life stage is required in order to identify areas producing high-quality spawners (i.e. with low contaminant and parasite burdens), to maximise protection for these areas.

In this paper, we use the term eel quality to indicate the health status. In the terms of references of the ICES/EIFAC Working Group on Eels (2006), the term 'quality of spawners' is suggested to be included in the stock management advice, describing "the capacity of silver eels to reach spawning areas and to produce viable offspring", and this term was used in relation to the quantification of the impact of pollution and parasitism (WG Eel 2006). Assessment of effective spawner biomass across the international range of eel requires a comprehensive compilation of eel quality data over its distribution area. During the last decade, many EU member states have collected data on the quality of eels in their water bodies. The objectives of these national initiatives are quite diverse, ranging from academic 
epidemiological studies into an individual disease agent, studies to quantify eel spawner quality, monitoring programs for the presence of chemicals in the environment (e.g. for the WFD) or even analytical work into hazardous substances in eels to determine if safe human consumption limits have been exceeded. The need for international coordination has been underlined. To this end, an initiative has been taken within the actions of the Joint EIFAC/ICES Working Group on Eels during its 2007 session. The objectives were (1) to collate recent data of contaminants and diseases of eels available over the distribution area of the eel, (2) to initiate the set up of a European Eel Quality Database (EEQD), (3) to get a view on constraints and problems, (4) to achieve preliminary analysis of the data and (5) to assess the possibilities of elaborating a strategy for Europe wide monitoring of eel quality.

The aim of the present paper is to present this ongoing work, with the purpose also to disseminate information about the existence of such a database, in order to promote its compilation.

\section{The European eel quality database}

The EEQD is coordinated by INBO, the Research Institute for Nature and Forest (Belgium), on the basis of the experience developed with the pollutant monitoring network in Flanders using eel as a sentinel species. Initially, only about 30 chemicals (PCBs, pesticides and heavy metals) were included, but in 2008 WG Eel decided to extend the list with a number of toxic and bioaccumulative substances as data became available. Dioxins, BFRs and perfluorinated compounds were added, as well as non-ortho and mono-ortho PCB congeners as these exhibit the highest dioxinlike toxicity and contribute most to the toxic equivalency (European Commission 2002). At the moment, the database includes information of ca. 90 chemicals (including individual congeners and derivates), but can be extended with other substances whenever needed. Also, fat content in muscle tissue was brought in as a proxy for fish condition. With regards to disease agents, among others the swimbladder nematode $A$. crassus was included, as this is believed to be one of the most invasive and debilitating parasites to eel (Palstra et al. 2007) and many studies have been carried out throughout Europe since its initial introduction in the early 1980s (Kirk 2003). An overview of the elements considered in the database is presented in Table 1 . To allow easy import of data by various users in different countries, the database is based on a Microsoft Office Excel 2003 application, but this will be upgraded to more appropriate database software in future. Currently, the database consists of one worksheet with text (instruction manual) and nine data worksheets comprising data on fat levels, PCBs, OCPs, heavy metals, dioxins, BFRs, other contaminants, Anguillicoloides and other diseases. For the lipophilic contaminants, data are expressed on wet weight (w.w.) and lipid weight (l.w.) basis. In each data worksheet the relevant descriptors of date and location of sampling, sample characteristics (eel life stage (glass eel, yellow eel or silver eel), number and morphometrics such as total length and weight), report reference and, eventually any remarks, are provided for each entry. A Word file is annexed to the database with all full references of the data in the EEQD.

The second step was the submission of the database to member countries, by circulating it amongst the members of the Joint EIFAC/ICES Working Group on Eels, in order to assess the availability of eel quality data. Fourteen countries submitted data for inclusion into the EEQD: fourteen submitted data on fat and PCBs content and eleven on eel pathogens (Table 2). The data were provided as both published and non published work by fisheries institutes, environmental agencies and universities through national representatives in the Working Group on Eel. Data sources are heterogeneous, data deriving most from national or local level monitoring surveys, but also from eco-toxicological studies or occasional researches.

Currently, EEQD is covering information from ca 75 references. Belgium has presented the most exhaustive information, due to the availability of data from the Flemish eel pollution network, in place since 1994 (Belpaire and Goemans 2007a) and contaminant data from the Walloon region (Thomé et al. 2004). The longest data series for bioaccumulation of contaminants is, however, 
Table 1 Overview of information and eel health descriptors included in the European Eel Quality Database

\begin{tabular}{|c|c|}
\hline \multicolumn{2}{|l|}{ Record attributes } \\
\hline Sampling site & Country, basin, name of lake, river, canal, estuary or fjord, locality, geocoordinates \\
\hline Sample and period & $\begin{array}{l}\text { Sampling year, number of eels in the sample, eel total length, eel weight, eel stage } \\
\text { (glass eel, yellow eel, silver eel), organ (e.g. muscle, liver, whole eel, ...) }\end{array}$ \\
\hline Report & Reference, remarks \\
\hline \multicolumn{2}{|l|}{ Condition } \\
\hline Fat content & Percent fat in muscle tissue \\
\hline \multicolumn{2}{|l|}{ Contaminants } \\
\hline Polychlorine biphenyls ${ }^{\mathrm{a}}$ & 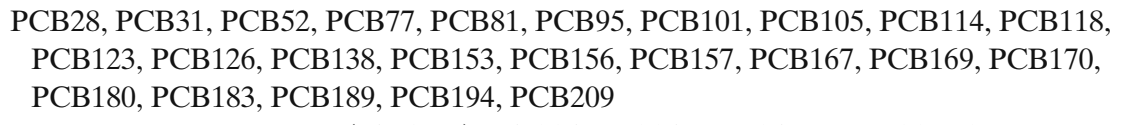 \\
\hline Pesticides $^{\mathrm{a}}$ & $\begin{array}{l}\alpha-\mathrm{HCH}, \beta-\mathrm{HCH}, \gamma-\mathrm{HCH} \text { (Lindane), Dieldrin, Aldrin, Endrin, Hexachlorobenzene } \\
(\mathrm{HCB}), p, p^{\prime}-\mathrm{DDD}(\mathrm{TDE}), p, p^{\prime} \text {-DDT, } p, p^{\prime} \text {-DDE, trans-nonachlor }\end{array}$ \\
\hline Heavy metals ${ }^{b}$ & $\mathrm{Cd}, \mathrm{Hg}, \mathrm{Pb}, \mathrm{Cr}, \mathrm{Ni}, \mathrm{Cu}, \mathrm{Zn}, \mathrm{As}, \mathrm{Se}, \mathrm{Mn}, \mathrm{Co}, \mathrm{V}, \mathrm{Ba}, \mathrm{Sr}$ \\
\hline Brominated flame retardants ${ }^{a}$ & $\begin{array}{l}\text { BDE } 28, \text { BDE 49, BDE 47, BDE 66, BDE 100, BDE 99, BDE 85, BDE } 154, \\
\text { BDE } 154+\text { BB153, BDE 153, BDE 183, sum PBDEs, HBCD }\end{array}$ \\
\hline Dioxins $^{\mathrm{a}}$ & $\begin{array}{l}\text { sum PCDD/Fs, sum DLPCBs, sum PCDD/Fs and DLPCBs, 2, 3, 7, 8-TetraCDD, } \\
\text { 1, 2, 3, 7, 8-PentaCDD, 1, 2, 3, 4, 7, 8-HexaCDD, 1, 2, 3, 6, 7, 8-HexaCDD, 1, 2, 3, 7, 8, } \\
\text { 9-HexaCDD, 1, 2, 3, 4, 6, 7, 8-HeptaCDD, OctaCDD (OCDD),-2, 3, 7, 8-TetraCDF, } \\
\text { 1, 2, 3, 7, 8-PentaCDF, 2, 3, 4, 7, 8-PentaCDF, 1, 2, 3, 4, 7, 8-HexaCDF, 1, 2, 3, 6, 7, } \\
\text { 8-HexaCDF, 1, 2, 3, 7, 8, 9-HexaCDF, 2, 3, 4, 6, 7, 8-HexaCDF, 1, 2, 3, 4, 6, 7, } \\
\text { 8-HeptaCDF, 1, 2, 3, 4, 7, 8, 9-HeptaCDF, OctaCDF (OCDF) }\end{array}$ \\
\hline PFOS $^{\mathrm{a}}$ & PFOS, PFHxS, PFOSA, PFOA, PFNA, PFDA, PFUnA \\
\hline \multicolumn{2}{|l|}{ Diseases } \\
\hline Parasites & $\begin{array}{l}\text { Anguillicoloides crassus, Pomphorhynchus laevis (abundance }{ }^{\mathrm{c}} \text {, } \text { prevalence }^{\mathrm{d}} \\
\text { and mean intensity of infection }{ }^{\mathrm{e}} \text { ) }\end{array}$ \\
\hline Bacteria and other lesions & $\begin{array}{l}\text { Edwardsiella, Vibrio or Aeromonas septicaemia, Herpesvirus anguillae } \\
\text { skin injuries caused by bacteria or fungi }\left(\text { prevalences }^{\mathrm{d}}\right)\end{array}$ \\
\hline
\end{tabular}

For condition and contaminants, data are presented as minimum, maximum and mean values

${ }^{\text {a Expressed as }} \mathrm{ng}^{-1}$ body weight or $\mathrm{ng} \mathrm{g}^{-1}$ lipid weight

${ }^{b}$ Expressed as $\mathrm{ng} \mathrm{g}^{-1}$ body weight

${ }^{\mathrm{c}}$ Total number of nematodes per eel including uninfected specimens

${ }^{\mathrm{d}}$ Number of infected eels divided by the total number of eels investigated at each site

${ }^{\mathrm{e}}$ Mean of the number of adult nematodes per infected eel

from the Netherlands, where a monitoring network for PCBs, OCPs and mercury in eel is in place since 1977 , linked to the safety for human consumption standards. Norway also disposes of a long time monitoring series of eels from the Grenland fjords (South Norway). This data series started in order to follow the development of polychlorinated dibenzo- $p$-dioxins and polychlorinated dibenzofurans (PCDF/PCDDs) in edible organisms after a $99 \%$ reduction in the load of waste components from the Hydro Porsgrunn magnesium factory (Knutzen et al. 2001). Germany and the United Kingdom have provided data on concentration of pollutants and contaminants relative to some river basins, carried out within local monitoring programmes (e.g. for Scotland, Macgregor et al. 2010). Some countries (e.g. Italy, Portugal, Spain) did report data drawn from ecotoxicological studies carried out within specific researches. In France, a PCB surveillance program has been started recently and several fish species (including eel) have been analysed in a considerable number of sites (Eaufrance 2010). The newest focus on both evaluating the chemical status in biota for the WFD and evaluating the status of the eel through the E.U. Data Collection Regulation, generates a significant increase in available data (e.g. Kelly et al. 2009, 2010; O'Leary et al. 2009; Nagel 2010). Besides, many unpublished results are available in some countries as grey literature, 
Table 2 Number of records of eel quality data over quality elements reported by European countries and compiled by WG Eel (2007-2010) in the European Eel Quality Database

\begin{tabular}{|c|c|c|c|c|c|c|c|c|c|}
\hline$\overline{\text { Country }}$ & Fat & PCBs & OCPs & $\begin{array}{l}\text { Heavy } \\
\text { metals }\end{array}$ & BFRs & Dioxins & PFOS & Anguillicoloides & $\begin{array}{l}\text { Other } \\
\text { diseases }\end{array}$ \\
\hline Belgium & 457 & 456 & 373 & 373 & 24 & 8 & & 140 & \\
\hline Denmark & 7 & 6 & 6 & & 4 & & 12 & 3 & \\
\hline France & 290 & 302 & & 3 & & & & & \\
\hline Germany & 54 & 12 & 23 & 23 & & 30 & & 54 & 6 \\
\hline Ireland & 20 & 16 & 14 & & 7 & 14 & & 121 & \\
\hline Italy & 34 & 34 & 28 & 7 & & & & 10 & \\
\hline Luxembourg & 3 & 3 & & & & & & & \\
\hline Norway & 8 & 8 & 8 & & & & & & \\
\hline Poland & 7 & 12 & 7 & 7 & & 7 & & 21 & \\
\hline Portugal & 1 & 1 & & 12 & & & & 9 & \\
\hline Spain & 18 & 60 & 73 & 53 & & & & 75 & 6 \\
\hline Sweden & 25 & 12 & 3 & 179 & & 9 & & 51 & \\
\hline The Netherlands & 119 & 181 & 99 & 76 & & 82 & & 10 & 10 \\
\hline United Kingdom & 31 & 67 & 66 & 39 & & & & 19 & 1 \\
\hline TOTAL & 1074 & 1170 & 700 & 775 & 35 & 151 & 12 & 513 & 23 \\
\hline
\end{tabular}

and need inclusion in the database. It is expected that in next future more eel quality data will become available as EU countries will have to report on the quality of the eel in their eel management units as described in the guidelines for the eel management plans. In addition, several new international and national research initiatives dealing with the quality of eels have been starting (e.g. the FP7 research project Eeliad), hence new data on the health status of eel and its potential impact on effective spawner biomass will become available.

Overall, eel quality data were provided for approximately 1,200 sites over Europe. The EEQD now includes data from samples from more than 10,000 eels collected between 1994 and 2009. Spatially, sites range from south western locations in Portugal (Rio Mira) to north east for some fjords in Grenland (Norway). At the present however, the database is overbalanced, many of the sites being situated in Belgium, where intensive monitoring took place both in Flanders (376 sites, Belpaire 2008) and Wallonia (36 sites, Thomé et al. 2004), while other countries are underreported. Sampling densities differ considerably between countries, e.g. for PCBs between 0.11 (Portugal) and 149 (Belgium) records (number of samples analysed) per 10,000 $\mathrm{km}^{2}$ (see Fig. 1). Most information is available for PCBs $(1,170$ records), heavy metals (775 records) and OCPs (700 records) whilst 1,074 observations on lipid content were also included (Table 2). Apart from some observations on bacterial and viral diseases available for a few sites in Spain, United Kingdom, Germany and The Netherlands, disease agents included in the database are mainly restricted to the swimbladder nematode $A$. crassus, with 513 records across Europe.

\section{Shortcomings and future development of the eel quality database}

The setting up of the database appears promising: its feasibility has been assessed, the list of quality data and associated descriptors has been identified, and a preliminary dataset has been organised: the first pan-European overview of eel quality data. Its major objective has been clearly defined, i.e. to collect and compile available information on eel quality, at the moment widely scattered over environmental agencies, research institutes, administrations, fisheries managers, eel scientists, parasitologists, toxicologists, food safety monitoring agencies. Currently, the main limiting factor is for various reasons, not all existing information could be assembled into 


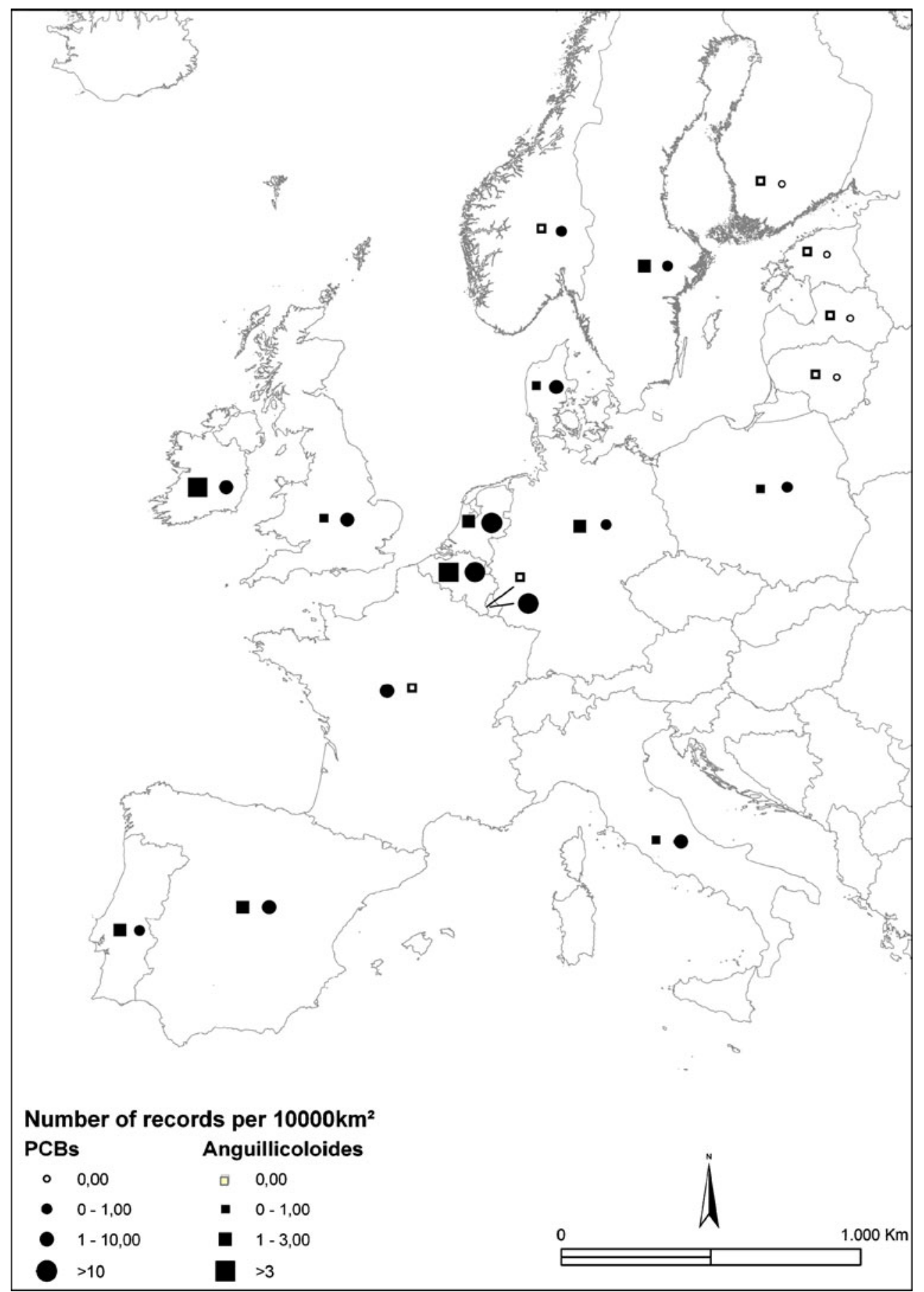

Fig. 1 Densities of records of PCBs and the swimbladder nematode Anguillicoloides crassus in eel in European countries

the database. Therefore further efforts will be directed towards its broadening, by contacting all the potential data providers by all possible infor- mation channels. The present paper represents a useful tool to reach a maximal number of data providers. A further step to facilitate new entries, 
and the keeping up to date of the database, could be to develop the current database version into a powerful user-friendly and web-based database. This will allow, besides data submission, making data available for all interested parties, allowing easy access and enabling analytic queries and cartographic applications.

There is still a need to broaden the list of chemical substances in the database. It may be necessary to prioritise the inclusion of chemical quality elements (1) which have been reported as harmful for eel and which may impair normal migration and/or reproduction, or (2) which have been identified as priority hazardous substances to monitor in our water bodies under the Water Framework Directive (WFD, European Commission 2008) or which are recognized as harmful by other international conventions or agreements (e.g. OSPAR guidelines for marine environmental assessments, ICES 2006) or (3) which are regulated for the protection of human health and where consumption limits are available (European Commission 1986, 2001, 2005, 2006).

The value of a database depends on the quality of the data, on their accuracy and integrity and also on their conformity to a definite standard (Weisbrod et al. 2007). The EEQD incorporates monitoring data collected for diverse objectives. One should be aware that the rationale for the monitoring may differ considerably between countries or reports. Efforts to monitor the health status of eel in a certain country are not always designed to be representative for the whole country or area. If eel contaminant monitoring in Wallonia (Thomé et al. 2004), Flanders (e.g. Belpaire et al. 2011) and Scotland (Macgregor et al. 2010) is based on random sampling and hence results may be regarded as representative for the whole country, this is not the case in many other reports where eel pollution monitoring is focussed on areas known to be polluted, or on specific areas for some other reasons. For example, in Luxembourg, Boscher et al. (2007) monitored PCBs and heavy metals in eel in rivers from the North of the country to evaluate potential impact on the otter (Lutra lutra). In Poland, Szlinder-Richert et al. (2010) analysed contaminants in eels from the Vistula and Szczecin lagoons in order to estimate eventual risks for human health, while in France
PCB monitoring in eel is focussed towards sites known for their high PCB levels in sediment, or sites with professional fisheries (AFSSA 2009). As a result, data from biased sampling might hinder drawing pertinent conclusions on a wider scale e.g. with respect to the global health status of the total stock and great care should be taken when analyzing and interpreting the EEQD data.

Furthermore, preliminary analysis of the data revealed some variation in methodologies. Most contaminant analyses are carried out on eel muscle tissue, but some data, e.g. heavy metal content refer to analysis on whole eel, or on specific organs, such as the liver or the gill. In some countries, data were submitted for silver eels, rather than yellow eels. Analytical methodology is likely to vary between labs, but it is not integrated into the database and can be found in the referred reports. Data reported from one site may be the result from the analysis of a single eel, the mean of several individual eels, or the result from a pooled sample of several eels. Data are indicated as minimum, maximum and mean values, but in some cases data are submitted as median values. Especially for the lipophilic compounds, results are sometimes expressed as concentrations on lipid weight, body weight or dry weight basis and papers do not always provide sufficient information for conversion of these units. In other cases (mostly older reports), derived data are presented in a graph but raw data are not available. Other problems encountered are difficulties with localisation of sampling sites. Published papers sometimes omit to present exact georeferences, or use local national georeference systems.

We therefore recommend that guidelines should be developed for the sampling and analysis of contaminants in eel from fresh water environments, similarly as has been the case in marine ecosystems. The OSPAR Joint Assessment and Monitoring Programme (JAMP) drafted guidelines for monitoring contaminants in biota and described how to perform accurate sampling and analysis of contaminants in fish, shellfish and seabird eggs, including the description of technical details concerning sampling, analysis, quality assurance and reporting (OSPAR 1999). Other contaminants were described recently in technical annexes (BFRs, polycyclic aromatic hydrocarbons, 
perfluorinated compounds and tributyltin) and dioxins and dioxin-like PCBs are in preparation. Joint actions with other ICES expert groups like the Marine Chemistry Working Group or the Working Group on biological effects of Contaminants could be helpful.

Long-term management of the eel quality database are also a complicating factor, as no one individual or state agency can commit necessary skills or resources on an open time frame basis. WG Eel (2009) suggested that the eel quality database should be managed at an international level (e.g. by ICES (ICES Data Centre) or some European agency, with long-term funding options and database management expertise).

\section{Applications}

At present, the database is only available for members of the WG Eel in support of the international eel management. However, a Europeanwide database of eel quality data could represent a useful instrument for different purposes, related to eel management as well as to environmental issues and to human health concerns.

The availability of an international up-to-date database compiling a whole range of eel quality parameters over the distribution area of the European eel is an essential instrument within the national and international eel recovery programs. Use of the database and application of the results are multiple. The database enables the identification and designation of good quality sites where special measures for maximum protection of stocks and emigrating spawners of good quality can be proposed (e.g. restriction of fisheries, priority places for restocking, priority for habitat restoration measures, etc). Some preliminary data processing on the lipid content and concentrations of cadmium and PCBs across Europe evidenced a wide variability in the levels of these contaminants and the presence of "black spots" over the distribution area of the eel (WG Eel 2007). WG Eel (2008) reported from the EEQD data that only in 4 out of 13 countries, eels have a fat percentage above $20 \%$, the minimal lipid stor- age needed for a successful reproduction (Boëtius and Boëtius 1980; van den Thillart et al. 2004, 2005). WG Eel (2009) deduced from the database that overall PCB load in Denmark, Ireland and Norway seemed to be lower than in many other countries. Based on recent EEQD data, WG Eel (2010) presented a figure with PCB levels in eel from eight countries (Fig. 2a) and concluded that the majority of values exceeded the Belgian consumption limit. From data on $A$. crassus in the EEQD it is clear that the parasite is widespread over Europe, and only a few countries (Ireland, Italy, Spain, Sweden and Belgium) have reported sites free of the parasite. Figure $2 b$ presents the prevalence of $A$. crassus in four countries from recent data provided to EEQD, and has been used in the international advice on eel management (WG Eel 2010). As discussed earlier, please mind that the monitoring data may not be representative for the whole country (e.g. due to biased sampling or only very local data available).

From an environmental point of view it is clear that the database will give information about specific environmental chemical pressures and will indicate pollution areas for specific contaminants (Belpaire and Goemans 2007a). The database will allow quick overviews and follow-up of emerging problems of a chemical or epidemiological nature and can be used as an early warning system for the spread of new eel diseases or contaminants. It will also permit the in-depth analysis of eel quality on a Europe wide scale. Eel contaminant analysis can be used for the evaluation of the chemical status in biota in accordance with the WFD and the EEQD can integrate these data and make them available for eel stock management.

In some well-known heavily polluted areas, it has been advised that fishermen are prevented from consuming their catch of eels, as human intake of PCBs via the consumption of eels is of concern to human health (Bilau et al. 2007). The database will facilitate an overview of areas where the quality of eels is below that deemed suitable for human consumption (i.e. maximum PCB human consumption limits exceeded), and where adequate fisheries management measures, like closing fisheries or preventing consumption of eels, have been taken by local policy makers. 

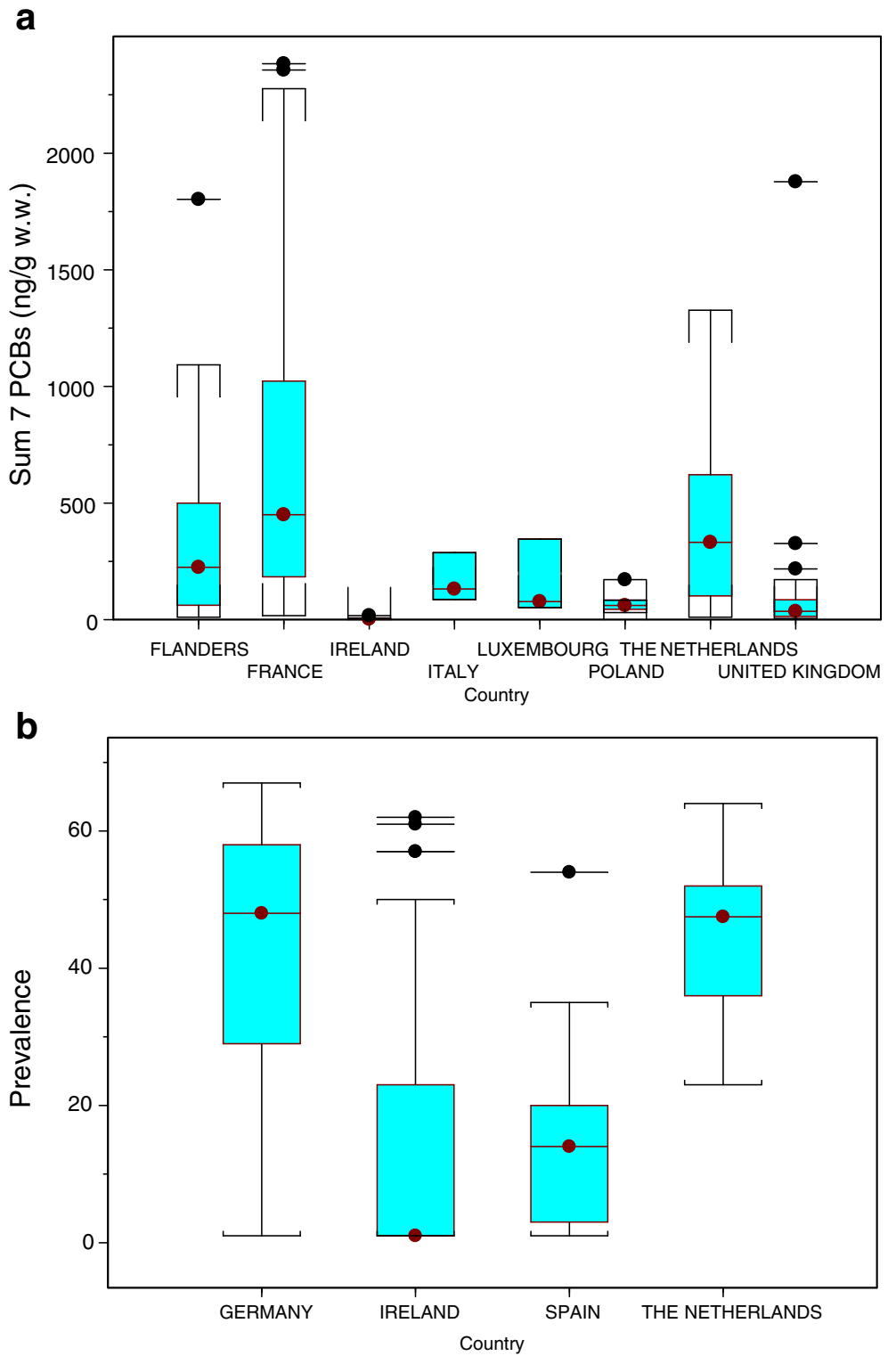

Fig. 2 Two examples of applications of the EEQD data in international advice (data from recent reports or data provided to EEQD during WG Eel 2010). Data is not always representative for the whole country, due to biased sampling or localised studies. a Sum 7 PCBs in ng/g w.w. in eel from various countries. Box plots are presenting median values, first and third quartiles, black dots are outliers. Data from UK are mainly from Scotland based on median values. Some outliers from France fall out the scale. Data from The Netherlands are Sum 6 PCBs. Origin and number of data: Flanders, Belpaire et al. 2011, $N=48$; France, Eaufrance (2010), $N=290$; Ireland, McHugh et al. (2010), $N=7$; Italy, Ferrante et al. (2010), $N=3$; Luxembourg, Boscher et al. 2007, $N=3$; Poland, Szlinder-Richert et al. (2010), $N=5$; The Netherlands, IMARES/RIKILT data,
$N=82$ and United Kingdom, Macgregor et al. (2010), $N=$ 21, Fernandes et al. (2009), $N=1$, Jürgens et al. (2009), $N=2$. b Prevalence of the swimbladder nematode $A n$ guillicoloides crassus in European eel from four European countries. Box plots are presenting median values, first and third quartiles. Origin and number of data: Germany, Fladung et al. (2009), $N=7$, Jakob et al. (2009), $N=$ 6, Nagel (2010), $N=12$; Spain, Costa-Dias et al. (2010), $N=19, N=1$; Ireland, Dooley, O'Neill and Poole pers. com., $N=6$, Kelly et al. (2009), $N=57$, Kelly et al. (2010), $N=44$, O'Leary et al. (2009), $N=7$, Spain, Esteve and Alcaide (2009), $N=2$, Muñoz et al. 2009, $N=2$ and the Netherlands, Haenen et al. 2010, $N=10$ (both figures are adapted from WG Eel 2010) 


\section{Conclusion}

The setting up of the European Eel Quality Database was a major and innovative outcome of the Joint EIFAC/ICES Working Group on Eels (2007). It represents the first comprehensive panEuropean overview of eel quality data, including data from over 10,000 eels from approximately 1,200 sites over 14 countries. The database will contain the eel quality data collected in the context of the monitoring within the eel management units, but will also contain data collected for a variety of purposes, such as chemical monitoring in the biota for the WFD, monitoring of consumption quality of fisheries products, academic research on toxicology or disease epidemiology. The EEQD provides a useful instrument for the compilation and scrutiny of these data, enabling the use of these results for the setting up of appropriate measures within future Eel Management Plans aimed at the restoration of the stocks.

The Joint EIFAC/ICES Working Group on Eels (2008) has recommended that the European Eel Quality Database should be further developed and maintained (WG Eel 2008). Initiated in 2007 , the database has shown a number of shortcomings and future developments will be needed, especially regarding expansion of the quality elements recorded, harmonisation of the methodology, quality assurance, communication, and database design. The Joint EIFAC/ICES Working Group on Eels endorses the need to develop an international monitoring network on eel quality, and monitoring strategies for eel should be harmonised (WG Eel 2007, 2008, 2009, 2010). WG Eel (2009) emphasized the need to establish a comprehensive overview with improved spatial coverage of the quality of the silver eel population across Europe as an essential and urgent requirement. Guaranteeing further development of the database, harmonisation of methods, quality assurance, and setting up eel monitoring strategies over Europe will be a great challenge and will need pan-European cooperative work. Finally, as recommended by WG Eel (2010), further development and management of the EEQD need support at the international level.
Acknowledgements We thank all members of the Joint EIFAC/ICES Working Group on Eels at the Bordeaux 2007, Leuven 2008, Göteborg 2009 and Hamburg 2010 meetings for valuable comments and contributions, in particular those people providing eel health data (published and non-published) for inclusion in the European Eel Quality Database. Also many other owners of non published data kindly agree in the use of their data for Fig. 2. Full reference of the origin of the data included in the database can be found in the Annex 6 of WG Eel (2007), in Chapters 9 of WG Eel (2008) and WG Eel (2009), and in Chapter 5 of WG Eel (2010). We are grateful to Yves Maes for drawing the map and two anonymous reviewers for their constructive comments on the manuscript.

\section{References}

AFSSA (2009). Appui scientifique et technique de l'Agence française de sécurité sanitaire des aliments relatif à l'interprétation des données du plan national PCB 2008 dans les poissons de rivière et à la proposition $d u$ plan d'échantillonnage 2009. Afssa saisine $\mathrm{n}^{\circ} 2009$ SA-0118. http://www.pollutions.eaufrance.fr/pcb/doc/ AvisASTechantillonnage0809.pdf.

Belpaire, C., \& Goemans, G. (2007a). Eels: Contaminant cocktails pinpointing environmental pollution. ICES Journal of Marine Science, 64(7), 1423-1436.

Belpaire, C., \& Goemans, G. (2007b). The European eel Anguilla anguilla, a rapporteur of the chemical status for the Water Framework Directive? Vie et MilieuLife and Environment, 57(4), 235-252.

Belpaire, C. (2008). Pollution in eel. A reason for their decline? Ph.D. thesis Catholic University of Leuven, INBO.M.2008.2. Instituut voor Natuur- en Bosonderzoek, Brussels, 459 pages, III annexes.

Belpaire, C., Goemans, G., Geeraerts, C., Quataert, P., \& Parmentier, K. (2008). Pollution fingerprints in eels as models for the chemical status of rivers. ICES Journal of Marine Science, 65, 1483-1491.

Belpaire, C., Goemans, G., Geeraerts, C., Quataert, P., Parmentier, K., Hagel, P., \& De Boer, J. (2009). Decreasing eel stocks: The survival of the fattest? Ecology of Freshwater Fish, 18, 197-214.

Belpaire, C., Geeraerts, C., Roosens, L., Neels, H., \& Covaci, A. (2011). What can we learn from monitoring PCBs in the European eel? A Belgian experience. Environment International, 37, 354-364. doi:10.1016/j.envint.2010.10.006.

Bilau, M., Sioen, I., Matthys, C., De Vocht, A., Goemans, G., Belpaire, C., Willems, J. L., \& De Henauw, S. (2007). Polychlorinated biphenyl (PCB) exposure through eel consumption in recreational fishermen as compared to the general population, using a probabilistic approach. Food Additives and Contaminants, 24(12), 1386-1393.

Böetius, I., \& Böetius, J. (1980). Experimental maturation of female silver eels, Anguilla anguilla. Estimates 
of fecundity and energy reserves for migration and spawning. Dana, 1, 1-28.

Boscher, A., Gobert, S., Guignard, C., Ziebel, J., L'Hoste, L., Gutled, A. C. et al. (2007). Chemical contaminants in fish species from rivers in the North of Luxembourg: potential impact on the Eurasian otter (Lutra lutra). Chemosphere, 78, 785-972.

Bruslé, J. (1991). The eel (Anguilla sp) and organic chemical pollutants. The Science of the Total Environment, 102, 1-19.

Costa-Dias, S., Dias, E., Lobón-Cerviá, J., Antunes, C., \& Coimbra, J. (2010). Infection by Anguillicoloides crassus in a riverine stock of European eel, Anguilla anguilla. Fisheries Management and Ecology, 2010, 485-492.

de Boer, J., \& Hagel, P. (1994). Spatial differences and temporal trends of chlorobiphenyls in yellow eel $(A n-$ guilla anguilla) from inland waters of The Netherlands. The Science of the Total Environment, 141(1/3), $155-174$.

Eaufrance (2010). Site des données du plan national d'actions sur les PCB. http://www.pollutions. eaufrance.fr/pcb/ Accessed September 2010.

Esteve, C., \& Alcaide, E. (2009). Influence of diseases on the wild eel stock: The case of lake Albufera. Aquaculture, 289, 143-149.

European Commission (1986). Council Directive $86 / 363 /$ EEC of 24 July 1986 on the fixing of maximum levels for pesticide residues in and on foodstuffs of animal origin. Official Journal of the European Union, L221, 43-47.

European Commission (2001). Commission Regulation (EC) No. 466/2001 of 8 March 2001 setting maximum levels for certain contaminants in foodstuffs. Official Journal of the European Union, L70, 1-13.

European Commission (2002). Commission Directive 2002/69/EC of 26 July 2002 laying down the sampling methods and the methods of analysis for the official control of dioxins and the determination of dioxin-like PCBs in foodstuffs. Official Journal of the European Commission, 06.08.2002 L209, 5-14.

European Commission (2005). Commission Regulation (EC) No. 396/2005 of the European Parliament and of the Council of 23 February 2005 on maximum residue levels of pesticides in or on food and feed of plant and animal origin and amending Council Directive 91/414/EEC. Official Journal of the European Union, L70, 1-16.

European Commission (2006). Commission Regulation (EC) 199/2006 of 3 February 2006 amending Regulation (EC) No 466/2001 setting maximum levels for certain contaminants in foodstuffs as regards dioxins and dioxin-like PCBs. Official Journal of the European Commission, 04.02.2006 L32, 34-38.

European Commission (2007). Council Regulation (EC) No 1100/2007 of 18 September 2007 establishing measures for the recovery of the stock of European eel. Official Journal of the European Union, 22.9.2007 L248, 17-23.
European Commission (2008). Directive 2008/105/EC of the European Parliament and of the Council of 16 December 2008 on environmental quality standards in the field of water policy, amending and subsequently repealing Council Directives 82/176/EEC, 83/513/EEC, 84/156/EEC, 84/491/EEC, 86/280/EEC and amending Directive 2000/60/EC of the European Parliament and of the Council. Official Journal of the European Union, 24.12.2008 L348, 84-97.

Fernandes, A. R., Mortimer, D. N., Rose, M., Knowles, T. G., White, S., \& Gem, M. (2009). Occurrence of dioxins (PCDDs, PCDFs) and polychlorinated biphenyls (PCBs) in wild, farmed and processed fish, and shellfish. Food Additives and Contaminants B, 2, 15-20.

Ferrante, M. C., Clausi, M. T., Meli, R., Fusco, G., Naccari, C., \& Lucisano, A. (2010). Polychlorinated biphenyls and organochlorine pesticides in European eel ( $A n$ guilla anguilla) from the Garigliano River (Campania region, Italy). Chemosphere, 78, 709-716.

Fladung, E., Simon, J., \& Wolf, P. (2009). Erfassung, Bewertung und Maßnahmen zur Verbesserung der Bestandssituation des Aals im Brandenburger Einzugsgebiet der Elbe und Oder/Ücker. Report of the Institute of Inland Fisheries, Potsdam-Sacrow, p. 63.

Geeraerts, G., \& Belpaire, C. (2010). A review of the effects of contaminants on European eel. Ecotoxicology, 19, 239-266.

Haenen, O. L. M., Lehmann, J., Engelsma, M. Y., Stürenberg, F. J., Roozenburg, I., Kerkhoff, S., \& Breteler, J. K. (2010). The health status of European silver eels, Anguilla anguilla, in the Dutch River Rhine Watershed and Lake IJsselmeer. Aquaculture, 309, $15-24$.

ICES (2006). Report of the Working Group on Marine Chemistry (MCWG), 27-31 March 2006, ICES Headquarters, Copenhagen. Computer Management. p. 36. Available from http://www.ices.dk/reports/MHC/ 2006/MCWG06.pdf.

Jakob, E., Hanel, R., Klimpel, S., \& Zumholz, K. (2009). Salinity dependence of parasite infestation in the European eel Anguilla anguilla in northern Germany. ICES Journal of Marine Science, 66, 358-366.

Jürgens, M., Johnson, A., Chaemfa, C., Jones, K., \& Hughes, D. (2009). The organic chemical contamination of eels in the lower Thames in 2007. A report by $\mathrm{CEH}$ prepared for Darryl Clifton-Dey of the Environment Agency for England and Wales, Thames Region, United Kingdom, p. 19.

Kelly, F. L., Connor, L., Wightman, G., Matson, R. Morrissey, E., O'Callaghan, R. et al. (2009). Sampling fish for the Water Framework Directive-Summary Report 2008. Central and Regional Fisheries Boards report, Swords, p. 163.

Kelly, F. L., Harrison, A. J., Connor, L., Matson, R., Wightman, G., Morrissey, E. et al. (2010). Sampling fish for the Water Framework Directive-Summary report 2009. Central and Regional Fisheries Boards report, Swords, p. 157. 
Kirk, R. S. (2003). The impact of Anguillicola crassus on European eels. Fisheries Management and Ecology, 10, 385-94.

Knutzen, J., Bjerkeng, B., Green, N., Kringstad, A., Schlabach, M., \& Skåre, J. U. (2001). Monitoring of micropollutants in fish and shellfish from the Grenland fjors (S. Norway) 2000. Norsk institutt for vannforskning (NIVA). p. 230.

Macgregor, K., Oliver, I. W., Harris, L., \& Ridgway, I. M. (2010). Persistent organic pollutants (PCB, DDT, $\mathrm{HCH}, \mathrm{HCB} \& \mathrm{BDE}$ ) in eels (Anguilla anguilla) in Scotland: current levels and temporal trends. Environmental Pollution, 158, 2402-2411.

Maes, J., Belpaire, C., \& Goemans, G. (2008). Spatial variation and temporal pollution profiles of polychlorinated biphenyls, organochlorine pesticides and heavy metals in European yellow eel (Anguilla anguilla L.) (Flanders, Belgium). Environmental Pollution, 153, 223-237.

McHugh, B., Poole, R., Corcoran, J., Anninou, P., Boyle, B., Joyce, E. et al. (2010). The occurrence of persistent chlorinated and brominated organic contaminants in the European eel (Anguilla anguilla) in Irish waters. Chemosphere, 79, 305-313.

Muñoz, C., Martínez-Carrasco, C., Ruiz de Ybáñez, R., García-Ayala, A., \& Peñalver. J. (2009). Prevalencia de Anguillicola crassus (Nematoda, Dracunculoidea) en anguilas (Anguilla anguilla) silvestres procedentes de dos ecosistemas: la Albufera de Valencia y el Mar Menor (Murcia). XII Congreso Nacional de Acuicultura. Madrid. Noviembre 2009.

Nagel, D.C.F. (2010). Annex Country Report Germany 2010. German National Data Collection of European Eel (Anguilla anguilla) 2009-2010. In WG Eel (2010). Report of the 2010 Session of the Joint EIFAC/ICES Working Group on Eels, FAO European Inland Fisheries Advisory Commission; International Council for the Exploration of the Sea, Hamburg, 9-14 September 2010, EIFAC Occasional Paper, ICES CM 2010/ACOM: 18. Rome, FAO/Copenhagen, ICES. 2010. p 405-431. (Online).

O'Leary, C., Becerra Jurado, G., Cruikshanks, R., \& Gargan, P. (2009). Report on the National Eel Monitoring Programme. Central and Regional Fisheries Report, Dublin, p. 136.

OSPAR (1999). JAMP Guidelines for Monitoring Contaminants in Biota. Available via http://www.ices.dk/env/ guidelines/index.htm.

Palstra, A. P., van Ginneken, V. J. T., Murk, A. J., \& van den Thillart, G. E. E. J. M. (2006). Are dioxin-like contaminants responsible for the eel (Anguilla anguilla) drama? Naturwissenschaften, 93, 145-148.

Palstra, A. P., Heppener, D. F. M., van Ginneken, V. J. T., Székely, C., \& van den Thillart, G. E. E. J. M. (2007). Swimming performance of silver eels is severely impaired by the swim-bladder parasite Anguillicola crassus. Journal of Experimental Marine Biology and Ecology, 352(1), 244-256.

Robinet, T., \& Feunteun, E. (2002). Sublethal effects of exposure to chemical compounds: a cause for the decline in Atlantic eels? Ecotoxicology, 11, 265-277.
Szlinder-Richert, J., Usydus, Z., \& Pelczarski, W. (2010). Organochlorine pollutants in European eel (Anguilla anguilla L.) from Poland. Chemosphere, 80, 93-99.

Thomé, J. P., Bertrand, A., Brose, F., Carabin, O., De Pauw, E., Dukmans, C. et al. (2004). Evaluation du niveau de contamination des rivières par les PCBs et les dioxines. Report Université de Liège. Convention avec la Région Wallonne, Ministère de l'Aménagement du Territoire, de l'Urbanisme et de l'Environnement, Engagement no. 01/4143. p. 167.

van den Thillart, G. E. E. J. M., van Ginneken, V., Körner, F., Heijmans, R., Linden, R., \& van der Gluvers, A. (2004). Endurance swimming of European eel. Journal of Fish Biology, 65, 312-318.

van den Thillart, G. E. E. J. M., Dufour, S., Elie, P., Volckaert, F., Sebert, P., Rankin, C. et al. (2005). Estimation of the reproduction capacity of European eel. EELREP Final Report. p.272. Available via http://www.fishbiology.net/EELREP_final_report.pdf.

Weisbrod, A. W., Burkhard, L. P., Arnot, J., Mekenyan, O., Howard, P. H., Russom, C. et al. (2007). Review of fish bioaccumulation databases used to identify persistent, bioaccumulative, toxic substance. Environmental Health Perspectives, 115, 255-261. doi:10.1289/ehp.9424 [Online 30 October 2006].

WG Eel (2006). Report of the 2006 session of the Joint EIFAC/ICES Working Group on Eels, FAO European Inland Fisheries Advisory Commission, International Council for the Exploration of the Sea, Rome, 23-27 January 2006, EIFAC Occasional Paper No. 38, ICES CM 2006/ACFM: 16. Rome, FAO/Copenhagen, ICES. 2007. p. 352.

WG Eel (2007). Report of the 2007 Session of the Joint EIFAC/ICES Working Group on Eels, FAO European Inland Fisheries Advisory Commission; International Council for the Exploration of the Sea, Bordeaux, 3-7 September 2007, EIFAC Occasional Paper No. 39, ICES CM 2007/ACFM: 23. Rome, FAO/ Copenhagen, ICES. 2008. p. 138 (Includes a CD-ROM).

WG Eel (2008). Report of the 2008 Session of the Joint EIFAC/ICES Working Group on Eels, FAO European Inland Fisheries Advisory Commission; International Council for the Exploration of the Sea, Leuven, 3-9 September 2008, EIFAC Occasional Paper No. 43, ICES CM 2009/ACOM: 15. Rome, FAO/Copenhagen, ICES. 2009. p. 192 (Includes a CD-ROM).

WG Eel (2009). Report of the 2009 Session of the Joint EIFAC/ICES Working Group on Eels, FAO European Inland Fisheries Advisory Commission; International Council for the Exploration of the Sea, Göteborg, 7-12 September 2009, EIFAC Occasional Paper No. 45, ICES CM 2009/ACOM: 15. Rome, FAO/Copenhagen, ICES. 2010. p. 540 (Online).

WG Eel (2010). Report of the 2010 Session of the Joint EIFAC/ICES Working Group on Eels, FAO European Inland Fisheries Advisory Commission; International Council for the Exploration of the Sea, Hamburg, 9-14 September 2010, EIFAC Occasional Paper, ICES CM 2010/ACOM: 18. Rome, FAO/Copenhagen, ICES. 2010. 721p. (Online). 